\title{
Evaluation of Mustard Hybrid varieties in Gangetic Plains of West Bengal, India
}

\author{
Soumik Biswas ${ }^{1}$, Bishal Mukherjee ${ }^{1 *}$, Ammaruddin Munshi ${ }^{1}$, \\ Subrata Chongre ${ }^{1}$ and Manabendra Ray ${ }^{2}$ \\ ${ }^{1}$ Department of Agronomy, Bidhan Chandra Krishi Viswavidyalaya, \\ Mohanpur, Nadia- 741252, West Bengal, India \\ ${ }^{2}$ AICRP-IFS, Directorate of Research, Bidhan Chandra Krishi Viswavidyalaya,Kalyani, \\ Nadia- 741235, West Bengal, India \\ *Corresponding author
}

\section{A B S T R A C T}

Keywords

Mustard, Hybrid, Variety, Yield

Article Info

Accepted:

07 September 2019

Available Online:

10 October 2019
A field experiment was conducted to find out suitable hybrid variety among 6 mustard hybrid varieties (Kesari Gold, JD 6, B 85, RW 351, RW 8559 and B9) in terms of growth characteristics, yield attributing components and yield in randomized block design (RBD) at Central Research Farm of Bidhan Chandra Krishi Viswavidyalaya, Kalyani, West Bengal, during rabi seasons of 2016-17 and 2017-18respectively. The result of the experiment revealed that among the 6 mustard hybrids evaluated, Kesari Gold recorded highest seed yield (1797 kg/ha) followed by JD $6(1484 \mathrm{~kg} / \mathrm{ha})$ and RW $8559(1385.50 \mathrm{~kg} / \mathrm{ha})$ respectively. According to the result, Kesari Gold produced taller plants $(157.25 \mathrm{~cm})$ followed by RW $351(151.74 \mathrm{~cm})$ respectively. The pooled data revealed maximum number of primary branches per plant and highest number of siliqua/ plant with the variety Kesari Gold (6.53 and 236.75) respectively. Highest no. of seeds/siliqua (23.50) as well as maximum 1000 seed weight (4.94 g) was also found in Kesari Gold hybrid. According to the pooled data of 2016-17 and 2017-18, Kesari Gold recorded highest Oil (40\%) which was closely followed by JD 6 (37.50\%) respectively. So, mustard hybrid Kesari Gold found superior to all other tested hybrids in the experiment in respect to growth and yield components as well as seed yield and oil content also. Kesari Gold can be recommended for the farmers of this zone.

\section{Introduction}

Mustard (Brassica spp.) is the third important oilseed crop in the world after soybean and groundnut respectively. In India, mustard is the second important edible oil seed after groundnut. Rapeseed and mustard are the major oilseed crops, traditionally grown everywhere in the country due to their high adaptability in conventional farming systems. Growing of rapeseed-mustard as a second crop in rice-based system could bring an additional net income of Rs. 23127/- per hectare per annum following standard package of practice 
(Singh et al., 2010). Presently rapeseed mustard sown area in India is $6.70 \mathrm{mha}$, with a production of $7.88 \mathrm{mt}$ and the average productivity is $1188 \mathrm{kgha}^{-1}$ (Crop Production Statistics Information System, 2016), which needs to be enhanced upto $2562 \mathrm{kgha}^{-1}$ by 2030 for ensuring edible oil for attaining selfsufficiency (DRMR, 2011).In West Bengal, it is grown under sub-tropical climate as a cold weather crop under irrigated or restricted irrigated condition (Ray et al., 2015) where the state contributes only $6.07 \%$ to the national production (Economic Review, 2015). The productivity of the crop in the state $(1066 \mathrm{~kg} / \mathrm{ha})$ is quite lower than developed countries mainly due to cultivation of age-old varieties having low yield potential (De et al., 2014, Directorate of Agriculture, 2014-15).

Production potential of mustard can be fully exploited with suitable agronomic management and genotypes. Improved agrotechniques like use of improved cultivars, timely sowing, ridge and furrow sowing method, adequate nutrient supply, irrigation at critical stages, chemical weed management at critical period and use of plant growth regulators (PGR) are the keys to achieve higher productivity of the crop under fertile land situation. Selection of varieties depends mainly on the several factors e.g. method of sowing, crop rotation, pest and disease management, irrigation facilities, climatic conditions etc.

However, the trend of rapeseed-mustard cultivation in the state all together has been increasing during the last five years, the reason being the adoption of new varieties with improved yielding ability. With this background information, the present study was carried out for consecutive two years under gangetic plains of West Bengal to study the effect of mustard hybrids on growth and yield of mustardin gangetic alluvial soil of West Bengal.

\section{Materials and Methods}

The experiment was conducted during rabi seasonof two consecutive years 2016-17 and 2017-18at the Central Research Farm of Bidhan Chandra KrishiViswavidyalaya, Kalyani, West Bengal, which is located at $21^{\circ} 83^{\prime} 981^{\prime \prime} \mathrm{N}$ latitude and 87 $42^{\prime} 323^{\prime \prime} \mathrm{E}$ longitude. The study area falls under subhumid tropical climate zone with an average annual rainfall of about $1600 \mathrm{~mm}$, out of which about 70-90 per cent is received during South-West monsoon season (June to September) and minor amount (2.5 - 5 percent) during November to February, while 10 - 15 percent is received during March to May. The soil of the experimental field was a well-drained sandy clay loam (Inceptisol) with good water holding capacity and moderate fertility status. The experiment was laid out in randomized block design (RBD) involving six mustard hybrid varieties (Kesari Gold, JD 6, B 85, RW 351, RW 8559 and B9) which were replicated thrice. Seeds of all rapeseed and mustard varieties were sown on 12.11.2016 and 14.11.2017 respectively. The crop was fertilized with a uniform amount of nitrogen, phosphorus and potassium at the rate of 80,40 and $40 \mathrm{~kg} / \mathrm{ha}$ respectively. The $50 \%$ dose of $\mathrm{N}$ and full dose of P2O5 and $\mathrm{K} 2 \mathrm{O}$ were applied as basal. The rest amount of nitrogen was applied in two splits with the equal amount at 21 DAS and at 42 DAS. Recommended package of practice were followed for growing these crops and plant protection measures were adopted as and when necessary. The data on growth and yield attributes were recorded from 5 plants, selected randomly from each plot at harvest of crop. Plant height at harvest was recorded. Yield attributing characters like number primary branches/plant, number of siliqua/plant, number of seeds/siliqua and 1000 grain weight were taken following standard procedure. Seed weight and straw weight were taken from each plot excluding the border rows and converted into $\mathrm{kg} / \mathrm{ha}$. 


\section{Results and Discussion}

Plant height of all tested mustard cultivars represents one of the important growth characters. The no. of primary branches per plant, no. of siliqua/plant, siliqua length, no. of seeds/siliqua and test weight are important yield attributing character for Indian mustard. Effect of hybrid varieties on growth characteristics and yield components of mustard has been presented in Table 1. Plant height $(\mathrm{cm})$ at harvest was significantly influenced by different varieties during both the year of experiment (Table 1). Result of the experiment revealed that plant height at harvest varied significantly between 109.03to $163.38 \mathrm{~cm}$ during the year 2016-17 and 97.47 to $161.57 \mathrm{~cm}$ in $2017-18$ respectively. In terms of pooled data, Kesari Gold produced taller plants $(157.25 \mathrm{~cm})$ followed by RW 351 $(151.74 \mathrm{~cm})$ respectively. Lowest plant height was obtained in B9 hybrid $(103.25 \mathrm{~cm})$.

The result confirms observation of Banerjee et al., (2017) who concluded that selection of suitable rapeseed mustard cultivars should be based on different traits for more effective seed yield. No. of primary branches/plant was influenced significantly during both the years by the varieties (Table 1). Number of primary branches per plant varied by 5.25 to 7.00 during 2016-17 and 4.55 to 6.87 in 2017-18 with maximum in variety B9 (7.00) during first year and with Kesari Gold (6.87) in second year. The pooled data revealed maximum number of primary branches per plant with the variety Kesari Gold (6.53) respectively (Table 2). Similar findings was also reported by Das et al., (2019) where no. of primary branches were significantly influenced by varieties in 1st year and maximum no. were recorded by Kesari Gold (7).Sana et al., (2003) reported that, higher number of branches/plant is the result of genetic makeup of the crop and environmental conditions which play a remarkable role towards the final seed yield of the crop. Number of siliqua/ plant and siliqua length were significantly influenced by varieties. In the years 2016-17 and 2017-18, highest number of siliqua/ plant was recorded with variety Kesari Gold (220.50 and 253.00) followed by JD 6 (178.05 and 194.00) respectively. From pooled data, highest number of siliqua/ plant was observed with variety Kesari Gold (236.75). This finding was in line with Das et al., (2019) where Kesari Gold recorded maximum no. of siliqua/plant (367.93 and 306.90 respectively in 1 st and 2 nd year). Difference of siliqua number among different varieties may be due to genetic character. Somondal et al., (2012) recorded different number of siliqua/plant by different mustard varieties. From the pooled data of siliqua length of the varieties during both the years of experiment, it was observed that, highest siliqua length was found in B9 (5.90 $\mathrm{cm}$ ) which was closely followed by Kesari Gold $(5.65 \mathrm{~cm})$ respectively. Maximum no. of seeds/siliqua was recorded in Kesari Gold (19.20 and 27.80) during both the years of experiment. Highest no. of seeds/siliqua was found in Kesari Gold (23.50) followed by B9 (13.99) as per mean data. In case of 1000 seed weight significant variations were observed among all the varieties (Table 1). Identically, the highest 1000 seed weight $(4.94 \mathrm{~g})$ was recorded in the variety Kesari Gold while moderate seed weight found in RW 8559 (4.73 g) and JD $6(4.45 \mathrm{~g})$ as per pooled data of 2016-17 and 2017-18 respectively. Mondal et al., (1992) described that, weight of 1000 seeds varied from variety to variety and species to species. They found thousand seed weight $2.50-2.65 \mathrm{~g}$ in case of Improved Tori (B. campestris).

Production of higher yield by different varieties might be due to the contribution of cumulative effects of the crop characteristics viz., number of branches/plant, siliqua/plant and seeds/siliqua. 
Table.1 Growth characteristics and yield components of Mustard varieties

\begin{tabular}{|c|c|c|c|c|c|c|c|c|c|c|c|c|c|c|c|c|c|c|}
\hline \multirow[b]{2}{*}{ Varieties } & \multicolumn{2}{|c|}{$\begin{array}{l}\text { Plant Height } \\
(\mathrm{cm}) \text { at harvest }\end{array}$} & \multirow[t]{2}{*}{ Mean } & \multicolumn{2}{|c|}{$\begin{array}{c}\text { Primary } \\
\text { branches/plant }\end{array}$} & \multirow[t]{2}{*}{ Mean } & \multicolumn{2}{|c|}{ Siliqua/plant } & \multirow[t]{2}{*}{ Mean } & \multicolumn{2}{|c|}{$\begin{array}{c}\text { Siliqua } \\
\text { length }(\mathrm{cm})\end{array}$} & \multirow[t]{2}{*}{ Mean } & \multicolumn{2}{|c|}{ Seeds/siliqua } & \multirow[t]{2}{*}{ Mean } & \multicolumn{2}{|c|}{$\begin{array}{l}1000 \text { Seed } \\
\text { Weight (g) }\end{array}$} & \multirow[t]{2}{*}{ Mean } \\
\hline & $\begin{array}{l}2016- \\
17\end{array}$ & $\begin{array}{c}2017- \\
18\end{array}$ & & $\begin{array}{c}\text { 2016- } \\
17\end{array}$ & 2017-18 & & $\begin{array}{c}2016- \\
17\end{array}$ & $\begin{array}{c}2017- \\
18\end{array}$ & & $\begin{array}{c}2016- \\
17\end{array}$ & $\begin{array}{c}2017- \\
18\end{array}$ & & $\begin{array}{c}2016- \\
17\end{array}$ & $\begin{array}{l}2017- \\
18\end{array}$ & & $\begin{array}{l}2016- \\
17\end{array}$ & $\begin{array}{c}2017 \\
-18\end{array}$ & \\
\hline $\begin{array}{l}\text { Kesari } \\
\text { Gold }\end{array}$ & 162.63 & 151.87 & 157.25 & 6.20 & 6.87 & 6.53 & 220.50 & 253.00 & 236.75 & 5.43 & 5.87 & 5.65 & 19.20 & 27.80 & 23.50 & 5.25 & 4.63 & 4.94 \\
\hline JD6 & 129.10 & 161.57 & 145.33 & 6.15 & 5.07 & 5.61 & 178.05 & 194.00 & 186.02 & 4.30 & 5.37 & 4.83 & 11.50 & 13.07 & 12.28 & 4.00 & 4.91 & 4.45 \\
\hline B85 & 150.03 & 149.33 & 149.68 & 5.35 & 5.17 & 5.26 & 173.45 & 189.00 & 181.22 & 4.73 & 4.14 & 4.43 & 13.45 & 13.87 & 13.66 & 4.23 & 4.10 & 4.16 \\
\hline RW351 & 163.38 & 140.10 & 151.74 & 5.25 & 5.73 & 5.49 & 162.50 & 138.00 & 150.25 & 4.52 & 4.14 & 4.33 & 13.50 & 13.47 & 13.48 & 4.30 & 3.78 & 4.04 \\
\hline RW8559 & 158.48 & 131.50 & 144.99 & 5.40 & 5.67 & 5.53 & 146.40 & 159.00 & 152.70 & 4.36 & 4.17 & 4.27 & 13.05 & 13.60 & 13.33 & 5.18 & 4.29 & 4.73 \\
\hline B9 & 109.03 & 97.47 & 103.25 & 7.00 & 4.55 & 5.77 & 127.45 & 85.00 & 106.22 & 5.85 & 5.95 & 5.90 & 13.35 & 14.63 & 13.99 & 4.28 & 3.85 & 4.07 \\
\hline $\operatorname{SEm}( \pm)$ & 3.63 & 5.63 & 4.63 & 0.24 & 0.25 & 0.24 & 17.17 & 17.72 & 17.44 & 0.24 & 0.19 & 0.22 & 0.95 & 0.92 & 0.93 & 0.31 & 0.22 & 0.27 \\
\hline $\begin{array}{c}\text { CD at } \\
5 \%\end{array}$ & 10.95 & 17.35 & 14.15 & 0.72 & 0.76 & 0.74 & 51.75 & 54.58 & 53.17 & 0.74 & 0.59 & 0.66 & 2.86 & 2.83 & 2.85 & 0.92 & 0.66 & 0.79 \\
\hline
\end{tabular}

Table.2 Yield, Harvest Index and Oil (\%) of Mustard varieties

\begin{tabular}{|c|c|c|c|c|c|c|c|c|c|c|c|c|}
\hline \multirow[b]{2}{*}{ Varieties } & \multicolumn{2}{|c|}{ Seed Yield (Kg/ha) } & \multirow[t]{2}{*}{ Mean } & \multicolumn{2}{|c|}{$\begin{array}{c}\text { Straw Yield } \\
\text { (Kg/ha) }\end{array}$} & \multirow[t]{2}{*}{ Mean } & \multicolumn{2}{|c|}{$\begin{array}{c}\text { Harvest Index } \\
(\%)\end{array}$} & \multirow[t]{2}{*}{ Mean } & \multicolumn{2}{|c|}{ Oil (\%) } & \multirow[t]{2}{*}{ Mean } \\
\hline & 2016-17 & 2017-18 & & $\begin{array}{c}\text { 2016- } \\
17\end{array}$ & 2017-18 & & $\begin{array}{c}2016- \\
17\end{array}$ & $\begin{array}{c}2017- \\
18\end{array}$ & & 2016-17 & 2017-18 & \\
\hline $\begin{array}{c}\text { Kesari } \\
\text { Gold }\end{array}$ & 1825 & 1769 & 1797 & 3560 & 3728 & 3644 & 37 & 32 & 34.50 & 40 & 40 & 40 \\
\hline JD6 & 1419 & 1549 & 1484 & 2278 & 3753 & 3015.50 & 38 & 29 & 33.50 & 37 & 38 & 37.50 \\
\hline B85 & 1100 & 1204 & 1152 & 2025 & 3235 & 2630 & 35 & 27 & 31 & 36 & 35 & 35.50 \\
\hline RW351 & 1341 & 1420 & 1380.50 & 2188 & 2272 & 2230 & 38 & 38 & 38 & 35 & 36 & 35.50 \\
\hline RW8559 & 1369 & 1402 & 1385.50 & 2267 & 3457 & 2862 & 34 & 30 & 32 & 35 & 36 & 35.50 \\
\hline B9 & 1221 & 800 & 1010.50 & 2025 & 2116 & 2070.50 & 38 & 27 & 32.50 & 35 & 36 & 35.50 \\
\hline $\operatorname{SEm}( \pm)$ & 96.69 & 155 & 125.85 & 181.05 & 253 & 217.03 & 0.87 & 0.76 & 0.82 & 1.00 & 0.98 & 0.99 \\
\hline CD at $5 \%$ & 291.40 & 477 & 384.20 & 545.66 & 780 & 662.83 & 2.79 & 2.44 & 2.62 & 3.19 & 3.13 & 3.16 \\
\hline
\end{tabular}


Seed yield $(\mathrm{kg} / \mathrm{ha})$ as influenced by varieties has been presented in Table 2 and it differed significantly among the varieties. Among the varieties highest seed yield $(1825 \mathrm{~kg} / \mathrm{ha}$ and $1769 \mathrm{~kg} / \mathrm{ha}$ respectively in 2016-17 and 201718) was recorded by Kesari Gold which was significantly higher than all other 5 mustard hybrids. Pooled data revealed that, Kesari Gold recorded highest seed yield (1797 kg/ha) followed by JD 6 (1484 kg/ha) and RW 8559 $(1385.50 \mathrm{~kg} / \mathrm{ha})$ respectively. Oilseed Research Centre of Bangladesh Agricultural Research Institute (BARI) conducted an experiment with 16 varieties/lines of rapeseed and observed that BARI sharisa- 8 produced maximum seed yield.The straw yield $(\mathrm{kg} / \mathrm{ha})$ was significantly affected by different mustard hybrids. Highest straw yield $(3560 \mathrm{~kg} / \mathrm{ha}$ ) was recorded by Kesari Gold in1st year and in 2nd year it was recorded by JD $6(3753 \mathrm{~kg} / \mathrm{ha})$, which was at par with Kesari Gold. From pooled data, it was also noted that Kesari Gold (3644 kg/ha) has recorded highest straw yield followed by JD $6 \quad(3015.50 \quad \mathrm{~kg} / \mathrm{ha})$ respectively. There was significant difference among the varieties in respect to harvest index (Table 2). Result of the experiment revealed that harvest index varied significantly between 34 to $38 \%$ during the year 2016-17 and 27 to $38 \%$ in 2017-18 respectively (Table 2). In terms of pooled data, Kesari Gold has recorded highest harvest index $(34.50 \%)$ which was closely followed by JD 6 (33.50\%) and B9 $(32.50 \%)$ respectively. Oil\% also varied significantly among mustard hybrids. According to the pooled data of 2016-17 and 2017-18, Kesari Gold recorded highest Oil (40\%) which was closely followed by JD 6 $(37.50 \%)$ respectively.

So, from the above results and discussion it may be concluded that, mustard hybrid Kesari Gold found superior to all other tested hybrids in the experiment in respect to growth and yield components as well as seed yield and oil content also. Kesari Gold can be recommended as a suitable mustard hybrid for the farmers of gangetic plains of West Bengal. Productivity and profitability of rapeseedmustard in the major production domain of West Bengal could be increased through the cultivation of improved varieties using scientific approach.

\section{References}

Anonymous. Adaptation trail of rapeseed mustard. Jamalpur: Annual Research Report of RARS; (2012). p. 27-29.

Banerjee, H., Chatterjee, S., Sarkar, S., Gantait, S., Samanta, S. (2017). Evaluation of rapeseed-mustard cultivars under late sown condition in coastal ecosystem of West Bengal. Journal of Applied and Natural Science. 9(2): 940-949.

Crop Production Statistics Information System. (2016). Special Data Dissemination Standard Division, Directorate of Economics \& Statistics, Ministry of Agriculture and Farmers Welfare, Govt. of India, New Delhi. Available from URL: (http://aps.dac.gov.in/APY/Index.htm). Accessed on 11 August 2016.

Das, A., Ray, M., Murmu, K. (2019). Yield and Yield Attributes of Hybrid Mustard as Affected by Crop Geometry and Varieties. International Journal of Current Microbiology and Applied Science. 8(04): 2160-2166.

De, B., Das, B., Das, B. and Sinha, A. C. (2014). Effect of integrated nutrient management on yield, nutrient uptake and economics of rapeseed (Brassica campestris var. yellow sarson) in terai region of West Bengal. Journal of Crop and Weed, 10(1): 69-72.

Directorate of Agriculture. (2015). Economic Review, Statistical Appendix 2014-15, Directorate of Agriculture, Government of West Bengal, Kolkata, 
India.

DRMR, 2011. Vision 2030. Directorate of Rapeseed-Mustard Research, Bharatpur, 321-303 Rajasthan, Pp30.

Economic Review. (2015). Statistical Appendix. Department of Statistics and Programme Implementation. Government of West Bengal, India, Pp. 65.

Mondal, MR, Islam, MA, Khaleque, MA. (1992). Effect of variety and planting date on the yield performance of mustard and rapeseed. Bangladesh Journal of Agricultural Sciences. 19(92):181-188.

Ray, K, Sengupta, K., Pal, A. K. and Banerjee, H. (2015). Effects of Sulphur fertilization on yield, $\mathrm{S}$ uptake and quality of Indian mustard under varied irrigation regimes. Plant Soil Environment.61(1): 6-10.

Sana, M., Ali, A., Malik, MA. (2003). Comparative yield potential and oil contents of different canola cultivars (Brassica napus. L.). Pakistan Journal of Agronomy. 2(1): 1-7.

Singh, R. K., Singh, Y., Singh, A. K., Kumar, R. and Singh, V. K. (2010). Productivity and economics of mustard (Brassica juncea) varieties as influenced by different fertility levels under late sown condition. Indian J. of Soil Conservation.38(2): 121-124.

Somondal, P. (2012). Varietal evaluation of rapeseed and mustard in new alluvial zone of West Bengal. M. Sc. Thesis, B.C.K.V, Mohanpur, Nadia, p-40.

\section{How to cite this article:}

Soumik Biswas, Bishal Mukherjee, Ammaruddin Munshi, Subrata Chongre and Manabendra Ray. 2019. Evaluation of Mustard Hybrid varieties in Gangetic Plains of West Bengal, India. Int.J.Curr.Microbiol.App.Sci. 8(10): 585-590. doi: https://doi.org/10.20546/ijcmas.2019.810.065 